\title{
PROTECTION OF SUPPLIERS OF AGRICULTURAL AND FOOD PRODUCTS FROM UNFAIR TRADING PRACTICE
}

\author{
Andrej Mićovićl \\ *Corresponding author E-mail: andrej.micovic@kg.ac.rs
}

A R T I C L E I N F O
Review Article
Received: 06 November 2021
Accepted: 02 December 2021
doi:10.5937/ekoPolj2104131M
UDC 338.439:339.137.27

Keywords:

unfair trading practices (UTPS), prohibition, protection, supplier, buyer

JEL: $K 220$

\begin{abstract}
A B S T R A C T
The paper analyses unfair trading practices that arise as a result of imbalance in bargaining power between suppliers and buyers of agricultural and food products. Considering that unfair practices also exist in the relations established between consumers and traders, that special rules have been adopted in this regard, the peculiarities and differences that exist between these rules were first pointed out, i.e., in terms of the approach to regulating these practices. Furthermore, the classification of unfair trade practices as absolutely and relatively prohibited was performed, and, finally, the rules on the way in which suppliers are protected from unfair practices were set out. Basically, the method of protection (administrative protection, at the initiative of the competent authorities or at the request of relevant organizations and associations) justifies the adoption of special rules that establish an effective system of protection of suppliers from unfair trading practices.
\end{abstract}

(C) 2021 EA. All rights reserved.

\section{Introduction}

Farmers, processors, traders, wholesalers, retailers and consumers are all actors in the food supply chain. Smaller operators in the food supply chain are more prone to face unfair trading practices (UTPs) due to their, in general, weak bargaining power in comparison to the large operators in the chain. Unfair business conduct by operators wielding bargaining power that is not prohibited, or the existence of redress possibilities that lack effectiveness, are liable to undermine the economic viability of operators in the chain (Proposal UTPD, p. 1-2).

Imbalances in bargaining power between suppliers and buyers of agricultural and food products are a common occurrence. Those imbalances in bargaining power are likely to lead to unfair trading practices when larger and more powerful trading partners seek to impose certain practices or contractual arrangements which are to their advantage in

1 Andrej Mićović, Ph.D., Associate Professor, Faculty of Hotel Management and Tourism in Vrnjačka Banja, University of Kragujevac, Vojvođanska 5A, 36210 Vrnjačka Banja, Serbia, Phone: +381 3651500 24, E-mail: andrej.micovic@kg.ac.rs, ORCID ID (https://orcid. org/0000-0002-5988-4387) 
relation to a sales transaction. Furthermore, certain practices might be manifestly unfair even when both parties agree to them (Preamble, No. 1 UTDP). Having on mind that agricultural production is particularly fraught with uncertainty due to its reliance on biological processes and its exposure to weather conditions and that agricultural and food products are to a greater or lesser extent perishable and seasonal, protection against unfair trading practices has become more important for operators active in the agricultural and food supply chain (Preamble, No. 6 UTDP). Such protection creates the conditions to mitigate the costs and damage suffered by producers due to unfair trade practices. ${ }^{2}$

Measures to combat UTPs have developed significantly in recent years. Many Member States, have recently introduced legislative and enforcement measures in order to create an effective framework to protect suppliers from unfair practices in the supply chain of agricultural and food products (out of the 20 Member States that already have legislation, 15 have introduced it in the last 5 years) (Report UTPs, p. 3). However, the state's rules on unfair trade practices are very different. It is noticeable that EU Member States have chosen different approaches to combat abuse. Some countries (for example, Germany and Austria) have regulations that require an assessment on a caseby-case basis of whether there is a significant economic imbalance between two market entities and whether a stronger entity has abused its position to impose unfair terms on the weaker party. Other Member States (i.e. Czech Republic, Slovakia, Hungary) have adopted regulations that contain a list of practices that are considered essentially unfair and therefore illegal (blacklists), i.e., fairness assessment is not made on a case-by-case basis (Ibidem, p. 6). The divergence of Member States' regulatory approaches to UTPs results furthermore in dissimilar conditions of competition for operators (Proposal UTPD, p. 2). This is the reason why the Proposal for a Directive on unfair trading practices in business-to-business relationships in the food supply chain pointed out the need to introduce minimum standard of protection against certain manifestly unfair trade practices in order to reduce the occurrence of such practices and to contribute to ensuring a fair standard of living for agricultural producers (Preamble, No. 7). This position was strengthened by the adoption of Directive 2019/633/EU (UTPD), which finalized the process that began a decade earlier with a focus on the functioning of the food supply chain and the emergence of unfair trade practices. ${ }^{3}$ The adoption of the UTPD ensured significant protection to all agricultural producers and organizations from unfair trade practices, which should eventually encourage young farmers to continue farming and stay in rural areas (in surveys they cited unfair practice as the

2 According to a 2013 survey of agricultural producers and agricultural cooperatives based on a wide definition of UTPs, the estimated damage from UTPs amounted to over EUR 10 billion per year. (Proposal UTPD, p. 10).

3 On 28 October 2009, the Commission published a Communication on the better functioning food supply chain in Europe (COM/2009/591), followed by a Communication on 15 July 2014 on tackling unfair trading practices in the business-to-business food supply chain companies (COM/2014/0472 final) and a Report on 29 January 2016 on unfair trading practices in the food supply chain (COM/2016/32 final). 
main reason for leaving agriculture) (https://ec.europa.eu/info/food-farming-fisheries/ key-policies/common-agricultural-policy/ market-measures/agri-food-supply-chain/ unfair-trading-practices_en).

Besides UTPD, unfair trade practices were previously regulated at the EU level by the Directive 2005/29/EC (UCPD). Both directives have been adopted for the purpose of eliminating differences between the laws of the Member States relating to unfair commercial practices in order to ensure fair competition and smooth functioning of the internal market (Preamble, No. 3 UCPD). Notwithstanding the fact that both directives are dealing with unfair trading practices, there are significant differences between them. These differences will be discussed first, followed by the rules contained in UTPD on forms of unfair practice and the enforcement authorities, which are competent to conduct proceedings and impose measures in order to prevent unfair practices.

\section{Peculiarity and differences between directives governing unfair practices}

Prior to the adoption of UTPD, there were no regulations at EU level targeting unfair trade practices among actors in the supply chain of agricultural and food products. Some countries have addressed this gap by extending the application of the rules set out in UCPD to business-to-business (B2B) transactions. ${ }^{4}$ However, the practices referred to in UCPD are mostly different tha the ones covered by UTPD (Report UTPs, p. 3). UCPD addresses commercial practices directly related to influencing consumers' transactional decisions in relation to products (Preamble, n. 17). Unfair commercial practice impairs the consumer's ability to make an informed decision, thereby causing the consumer to take a transactional decision that he would not have taken otherwise (Art. 2, par. 1(e) UCPD). ${ }^{5}$ In contrast, UTPD covers unfair commercial practices through which a more powerful trading partner seek to impose certain practices or contractual arrangements which are to their advantage in relation to a sales transaction of agricultural or food products (Preamble, no. 1 UTPD). Therefore, essential differences between unfair practices regulated by UCPD and UTPD can be identified, in terms of their effect, subjects of protection and objects in relation to

4 Seven EU Member extended the application of UCPD to business-to-business transactions: Austria, Sweden, Denmark, France, Germany, Italy and Belgium. For those Member States which have extended all (Austria and Sweden) or part (Denmark, France, Italy) of the provisions contained in the UCPD to B2B transactions, the UCPD provisions as transposed into national laws will in practice replace the relevant Misleading and Comparative Advertising Directive provisions in B2B relations. It should be noted that some countries (Belgium) have also adopted specific rules for B2B. See: Mihajlović, p. 808; SWD/2016/0163 final)

5 The existence of a contractual relationship between the trader and the consumer is not a necessary condition for the application of the general prohibition of unfair business practices. However, in order to support consumer confidence the general prohibition should apply equally to unfair commercial practices which occur outside any contractual relationship between a trader and a consumer or following the conclusion of a contract and during its execution (Preamble, No. 13). See: Mihajlović, p. 805; Đurović, p. 175. 
which protection is granted. In the case of UCPD, the subjects of protection are consumers in connection with the purchase and use of any product. When it comes to UTPD, the subject of legal protection are suppliers, ${ }^{6}$ in connection with the trade of agricultural or food products, i.e., services related to the purchase of agricultural and food products.

The rules, which are contained in the directives, seek to combat unfair practices that arise as a result of inequality of actors involved in transactions. When it comes to the consumer, the relationship between the trader and the consumer, which is a priori unequal, justifies a special consumer protection regime (Mićović, M., Mićović, A., p. 25). Basically, consumers are protected because they do not have the necessary knowledge (expertise) and experience in relation to a sales transaction, which could lead to an unfairly unfavorable position in relation to a trader (Keirsbilck, p. 241-242). Suppliers, as subjects of protection under UTPD, are protected if they have subordinate position in economic terms in relation to the buyers of their products. The process of defining subject matter and legal scope of the rules governing unfair trading practice at the EU level, has gone through two developmental stages. The Proposal for a Directive granted protection to small and medium-sized suppliers in the food supply chain when they sell food products to a buyer that is not a small and medium-sized enterprise (Art. 1, para. 2). A targeted protection of small and medium suppliers in the food supply chain was justified because they are often the ones who cannot defend themselves against UTPs due to their lack of bargaining power (Proposal UTPD, p. 1, 9). With the adoption of UTPD, the position on when there is a relationship of inequality, and thus the right of suppliers to protection, has changed. The criteria for determining inequality is no longer mere status of suppliers (micro, small, medium enterprises), but rather differences in bargaining power between suppliers and buyers. ${ }^{7}$ In case discrepancy in bargaining power exceeds the established limits, there will be a relationship of inequality and the right of suppliers to protection from unfair practices. Accordingly, UTPD provides applies to certain unfair trading practices which occur in relation to sales of agricultural and food products by: (a) suppliers which have an annual turnover not exceeding EUR 2000000 to buyers which have an annual turnover of more than EUR 2000 000; (b) suppliers which have an annual turnover of more than EUR 2000000 and not exceeding EUR 10000000 to buyers which have an annual turnover of more than EUR 10000 000; (c) suppliers which have an annual turnover of more than EUR 10000000 and not exceeding EUR 50000000 to buyers which have an annual turnover of more than EUR 50000 000; (d) suppliers which have an annual turnover of more than EUR 50000000 and not exceeding EUR 150000 000 to buyers which have an annual turnover of more than EUR 150000 000; (e) sup-

6 Supplier means any agricultural producer or any natural or legal person, irrespective of their place of establishment, who sells agricultural and food products; the term 'supplier' may include a group of such agricultural producers or a group of such natural and legal persons, such as producer organisations, organisations of suppliers and associations of such organisations (Art. 2. para. 1 (4) UTPD).

7 A dynamic approach, which is based on the relative size of the supplier and the buyer in terms of annual turnover, should provide better protection against unfair trading practices for those operators who need it most (Preamble of UTPD, No. 9) 
pliers which have an annual turnover of more than EUR 150000000 and not exceeding EUR 350000000 to buyers which have an annual turnover of more than EUR 350000 000 (Art. 1, para. 2). ${ }^{8}$ UTPD also applies to sales of agricultural and food products by suppliers which have an annual turnover not exceeding EUR 350000000 to all buyers which are public authorities. ${ }^{9}$

Unlike UCPD, which adopted a three-step assessment approach in determining fairness of a particular trader's business practice (general clause, which sets out the general conditions that must be met in order for a trader's business to be considered unfair; ${ }^{10}$ rules on misleading and aggressive commercial practices on the basis of which the unfairness of the practice is determined; a "blacklist" of commercial practices considered unfair regardless of the circumstances of the particular case) (Jovičić, p. 597; Mihajlović, p. 540; Radončić, p. 381), a simpler, two-step approach was adopted in UTPD: fairness assesment of trading practices is determined on the basis of the general clause and the enumeration of practices which are classified as absolutely and relatively unfair.

Although both directives envisage general clause, as a general rule for determining unfair practices, directives differently regulate composing elements of general clause which need to be cumulatively fulfilled. The existence of unfair commercial practices pursuant to UCPD requires two elements to be cumulatively fulfilled: first, the trader's conduct must be contrary to the requirements of professional diligence, ${ }^{11}$ and second, such conduct must distort or is likely to materially distort the economic behaviour

8 Concretization of this criteria enables "objectively subordinate supplier" to initiate proceedings against an "objectively stronger customer".

9 Public authority means national, regional or local authorities, bodies governed by public law or associations formed by one or more such authorities or one or more such bodies governed by public law (Art. 2, para. 1(3) UTPD).

10 The abstractness of the general clause ensures the sanctioning of every form of unfair practice, which enables adequate monitoring of market development and traders' business conduct (Đurović, p. 181).

11 According to the Art. 2, para. 1, point h) of the UCPD, professional diligence means the standard of special skill and care which a trader may reasonably be expected to exercise towards consumers, commensurate with honest market practice and/or the general principle of good faith in the trader's field of activity. This provision is more clearly defined in Serbian Law on Consumer Protection (Off. Gazette of the RS, No. 88/2021): professional diligence means increased care and skill which a trader may reasonably be expected to exercise towards consumers in business operation, commensurate with good business customs and the principle of good faith (Art. 5, para. 1, point 15). It remains unclear what level of professional diligence should be performed to be proportionate to good business customs and the principle of good faith. Bearing in mind that there are two degrees of professional diligence in accordance to which traders are obliged to act (due dilligence of a prudent businessman and due duligence of an expert), doctrinal view speaks in favor of the due duligence of an expert. That means that the trader is obliged to apply an increased level of due diligence, to adhere to the relevant professional and customary rules (Jovičić, p. 591). If we accept this justified doctrinal view, it remains unclear how the rules of the profession can be brought into some proportion to business morality and the principle of good faith and fair dealing. 
with regard to the product of the average consumer whom it reaches or to whom it is addressed, or of the average member of the group when a commercial practice is directed to a particular group of consumers (Art. 5 para. 2). In contrast to UCPD, UTPD determines the general clause by two different elements: first, it must be a practice which deviates from good commercial conduct or which is contrary to good faith and fair dealing, ${ }^{12}$ and second, that it is a matter of a practice unilaterally imposed by one trading partner on another (Art. 1, para. 1). Basically, behind the above elements are the basic principles of property law. When one party imposes something unilaterally on the other, it thereby violates the principle of equality of parties in contractual relations, which is based on the will of the parties, that must be equal and coordinated (Commentary about Law on Obligations, p. 107). If a party that violates the principle of equality imposes a practice that violates the principle of acting in accordance with good business practice or the principle of good faith and fair dealing, there is an unfair practice. Given that the existence of unfair practices requires a violation of the basic principles of property law, it seems justified that, if the method of enumeration is accepted, some other principles should be stated in the general clause. Such approach was taken, for example, in the Draft Law on Prohibition of unfair trade practices in the food supply chain of the Republic of Croatia, where it is determined that: unfair commercial practices are contractual provisions and/or business practices which unilaterally impose the buyer to the supplier, regarding the sale of agricultural and food products, using its significant bargaining power in relation to the supplier, contrary to the principle of good faith and fair dealing, the principle of equalilty of parties, the principle of equal consideration as well as contrary to good business practice in the production and/or trade of agricultural or food products (Art. 3, para. 1, item 2).

Different approach has been taken in the directives regarding the standard of protection against unfair practices. UCPD is based on the principle of maximum harmonisation of national regulations with the provisions of the directive. Not only is there a lower limit on the level of legal protection that Member States have to provide, but also an upper limit, which means that Member States are not allowed to set up a system that provides a higher level of protection than required by the directive. A high degree of harmonization, which is achieved by harmonizing national regulations with the rules of the directive, achieves a high general level of consumer protection (Lončar Velkova, Dabović Anastasovska, p. 157; Mišćenić, Mamilović, p. 276; Đurović, p. 173). UTPD adopted the principle of minimum harmonisation which include: a minimum list of prohibited unfair trading practices in relations between buyers and suppliers in the agricultural and food supply chain and minimum rules concerning the enforcement of those prohibitions (Art. 1 para. 1). The minimum harmonisation approach allows Member States to adopt or maintain national rules which go beyond the unfair trading practices listed in this Directive (Preamble, No. 1).

12 Traditional terms accepted in Serbian law regarding the first element, refer to a practice that is contrary to good business customs (business morality - unwritten but well-known ethical rules on behaviour of market participants) or the principle of good faith and fair dealing. 


\section{List of prohibited unfair trading practices}

Unfair trading practices, which are listed in UTPD, are characterized by the following: first, they are not exhaustive enumerations, which means that Member States may classify some other practices as unfair; second, all practices are divided into two groups, those that are absolutely prohibited, i.e., considered unfair regardless of the circumstances ("black" practices), and those that are relatively prohibited ("grey" practices), which means that they can be applied if, under clear and unambiguous conditions, they have been previously agreed under a supply contract or a subsequent contract concluded between the supplier and the buyer (the principle of autonomy of will applies to these practices, enabling parties to agree on the qualification of a particular practice). The rules on UTPs do not require operators to carry out certain activities, they only prohibit certain behaviour that is deemed unfair (Proposal UTPD, p. 10).

For easier monitoring, absolutely prohibited UTPs can be classified into five subgroups:

\section{Practice that violates the rule on the obligation of a written form of supply contract.}

- Although the use of written contracts should not be mandatory, it is considered that written form may help to avoid UTPs (Preamble, No. 23 UTPD). Therefore, suppliers have the right to ask the buyer to conclude a supply contract in writing. The refusal of the buyer to do so is subject to unfair trading practice, which is prohibited (Art. 3, para. 1, point f) UTPD).

Since commercial contracts are, as a rule, informal, in accordance with the rules contained in our General Customs, each party may request from the other party a written confirmation of the orally concluded contract. Such written confirmation may refer not only to the conclusion of the contract, but also to the facts that occur after the conclusion of the contract, and may be important for the contract performance (Goldštajn, p. 111). Knowing that Directive applies to UTPs, which can occur at any stage of the sale of agricultural and food products (before, during or after a sales transaction) (Preamble, No. 15 UTPD), the use of written confirmation in the supply chain of agricultural and food products may avoid UTPs, regardless of the stage of transaction.

2. Practices deviating from the principle of pacta sunt servanda. - Under the principle pacta sunt servanda contracting parties are obliged to fulfill their obligations under the conditions determined by the contract.

The principle pacta sunt servanda has no absolute effect, which means that under certain conditions contract provisions may be altered (Commentary about Law on Obligations, p. 161). Thus, the content of the supply contract may be altered by the will of the contracting parties, but not unilaterally, by the will of the buyer. Therefore, it is prohibited for the buyer to unilaterally change the terms of the supply agreement for agricultural and food products that concern the frequency, method, place, timing or volume of the supply or delivery of the agricultural and food products, the quality standards, the terms of payment or the prices (Art. 3. para. 1, point c) UTPD). Or, in the case of termination of obligations, under certain conditions they may be terminated 
based on a statement of the will of the buyer. The buyer can cancel the order of perishable products, provided that the notice period cannot be shorter than 30 days. Otherwise, the buyer's conduct would be unfair, because it cannot be reasonably expected that the supplier will find another way to use or place these products on the market (Art. 3, para. 1, point b) UTPD). Exceptionally, in justified cases for certain sectors, Member States could set deadlines of less than 30 days.

3. Practices involving certain payments and reimbursement of certain costs. - The following UTPs are prohibited under UTPD:

a) late payments, i.e., payments to the supplier after the expiration of prescribed deadlines (Art. 3, para. 1, point a). - According to the general rules of contract law, the time of payment is determined by the contract and there are three possibilities: payment as soon as the goods are delivered, payment before delivery and payment after delivery. In commercial relations, the rule is that sales are made on credit and, accordingly, the UTPD sets deadlines for payment after receipt of the delivery, i.e., the expiration of the delivery period. Payments that end after the prescribed deadlines are considered late. These payments negatively affect the economic sustainability of the supplier (Preamble, No. 17), which justifies prohibition of such practices.

What will be considered late payment depends on whether or not delivery of products on a regular basis has been agreed, as well as what is the subject of the contract, perishable ${ }^{13}$ or some other products. If the contract provides for regular delivery of perishable agricultural or food products on a regular basis, payment is late if it is made later than 30 days (or 60 days for other products) after the end of an agreed delivery period in which deliveries have been made or later than 30 days (or 60 days for other products) after the date on which the amount payable for that delivery period is set, whichever of those two dates is the later. Where the supply agreement does not provide for the delivery of perishable products on a regular basis, payment is late if it is made later than 30 days (or 60 days for other products) after the date of delivery or later than 30 days (or 60 days, in the case of other products) after the date on which the amount payable is set, whichever of those two dates is the later.

Where the buyer sets the amount payable and delivery on a regular basis is agreed, the payment periods shall start to run from the end of an agreed delivery period in which the deliveries have been made; and when no delivery on a regular basis is provided, the payment periods start to run from the date of delivery of agricultural and food products.

The prohibition, related to deliveries on a regular basis, does not apply to payments: made by a buyer to a supplier where such payments are made in the framework of the school scheme pursuant to Article 23 of Regulation (EU) No 1308/2013 (regulates the issue of EU assistance to Member States in terms of supplying children with fruit and vegetable

13 According to Art. 2, para. 1, point 5 UTPD, perishable agricultural and food products means agricultural and food products that by their nature or at their stage of processing are liable to become unfit for sale within 30 days after harvest, production or processing. 
products); made by public entities providing healthcare in the meaning of point (b) of Article 4(4) of Directive 2011/7/EU: under supply agreements between suppliers of grapes or must for wine production and their direct buyers ${ }^{14}$ (Art. 3, para. 1. UTPD).

b) the buyer requires payments from the supplier that are not related to the sale of the agricultural and food products of the supplier (Art. 3, para. 1, point d). - Suppliers and buyers of agricultural and food products are free, within certain regulations, to negotiate the conditions under which the sales transaction will be realized, which includes negotiations on the services that the buyer will provide to the supplier. However, if the buyer charges the supplier for payments that are not related to a particular sales transaction, this should be considered unfair and prohibited.

c) the buyer requires the supplier to pay for the deterioration or loss, or both, of agricultural and food products that occurs on the buyer's premises or after ownership has been transferred to the buyer, where such deterioration or loss is not caused by the negligence or fault of the supplier (Art. 3 para. 1. point e). - If the deterioration or loss of the product was not caused by the supplier's fault, in which case he would be liable for the material defects of the product, then the risk of accidental loss or damage to goods until delivery to the buyer shall be born by the seller, and on delivery of the goods the risk shall pass to the buyer (Art. 456, para. 1 of the Law on Obligations). With the delivery, buyer becomes the owner of the goods, and the rule is that the risk of accidental loss or damage to goods is borne by its owner (res perit domino). Therefore, if the buyer, contrary to the stated rule, points out the request that the supplier bears the damage, it is an unfair practice, which is prohibited.

d) the buyer requires compensation from the supplier for the cost of examining customer complaints relating to the sale of the supplier's products despite the absence of

14 Grapes and must for wine production have special characteristics, because grapes are harvested only during a very limited period of the year, but are used to produce wine which in some cases will only be sold many years later. In order to cater for that special situation, producer organisations and interbranch organisations have traditionally developed standard contracts for the supply of such products. Such standard contracts provide for specific payment deadlines with instalments. As those standard contracts are used by suppliers and buyers for multiannual arrangements, they not only provide agricultural producers with the security of longstanding sales relations, but also contribute to the stability of the supply chain. Where such standard contracts have been drawn up by a recognised producer organisation, interbranch organisation or association of producer organisations and been made binding by a Member State under Article 164 of Regulation (EU) No 1308/2013 ('extension') before 1 January 2019, or where the extension of the standard contracts is renewed by a Member State without any significant changes to the payment terms to the disadvantage of suppliers of grapes and must, the late payment provisions laid down in this Directive should not apply to such contracts between suppliers of grapes and must for wine production and their direct buyers (Preamble, No. 19 UTPD). The suppliers of wine can have crucial and determinant role in speed and quality of the development of wine tourism (Stojković, Milićević, p. 60). 
negligence or fault on the part of the supplier (Art. 3, para. 1, point i). - By analogy with the previously stated form of unfair practice, emphasizing such a request is prohibited.

\section{Practices of disloyal behavior of the customer (unlawful acquisition, use, disclosure} of trade secrets). - Businesses, irrespective of their size, value trade secrets as much as patents and other forms of intellectual property right. They use confidentiality as a business competitiveness tool (Preamble No. 2 of Directive 2016/943/EU). The unlawful acquisition, use or disclosure of a trade secret compromises legitimate trade secret holders' ability to obtain first-mover returns from their innovation-related efforts (Preamble No. 4 of Directive 2016/943/EU). The unlawful acquisition, use or disclosure of a trade secret by a third party could have devastating effects on the legitimate trade secret holder, as once publicly disclosed, it would be impossible for that holder to revert to the situation prior to the loss of the trade secret (Preamble No. 26 of Directive $2016 / 943 / \mathrm{EU})$. This is the reason why practice of the buyer to illegally obtain, use or disclose business secrets of suppliers in the sense of EU Directive 2016/943 is considered unfair and prohibited (Article 3, paragraph 1, item e). ${ }^{15}$

5. Practices aimed at causing fear of suppliers. - Fear of suppliers is caused by the so-called. measures of commercial retaliation.

When the buyer threatens the supplier by applying measures (e.g. by delisting products, reducing the quantities of products ordered or stopping certain services which the buyer provides to the supplier such as marketing or promotions on the suppliers' products), if the supplier exercises its contractual or legal rights, including by filing a complaint with enforcement authorities or by cooperating with enforcement authorities during an investigation, it is a matter of commercial retaliation, i.e., a form of unfair trading practice, which is prohibited (Art. 3, para. 1, item h).

According to UTPD, unfair practices will be considered relatively prohibited in case:

(a) the buyer returns unsold agricultural and food products to the supplier without paying for those unsold products or without paying for the disposal of those products, or both; (b) the supplier is charged payment as a condition for stocking, displaying or listing its agricultural and food products, or of making such products available on the market; (c) the buyer requires the supplier to bear all or part of the cost of any discounts on agricultural and food products that are sold by the buyer as part of a promotion; (d) the buyer requires the supplier to pay for the advertising by the buyer of agricultural and food products; (e) the buyer requires the supplier to pay for the marketing by the buyer of agricultural and food products; (f) the buyer charges the supplier for staff for fitting-out premises used for the sale of the supplier's products.

15 The Law on Trade (Off. Gazette RS, No. 52/19) stipulates that the actions of a trader aimed at acquiring, using and disclosing a trade secret without the consent of its owner, in order to aggravate his position on the market, are considered unfair competition (Art. 41, para. 1, point 4). 
Practices, that require a certain payment or bearing of cost, will be classified fair, if the payment is based on objective and reasonable estimates (Preamble, No. 26, 27 UTPD). In this regard, the buyer shall provide the supplier with an estimate in writing of the payments per unit or the overall payments, whichever is appropriate, as well as to provide, in writing, an estimate of the cost to the supplier and the basis for that estimate (Art. 3, para. 3 UTPD).

\section{Protection against unfair trading practices}

Unlike the solution adopted in UCPD, where Member States may opt for judicial or administrative protection of consumers from unfair commercial practices, UTPD adopted an administrative type of protection of suppliers from unfair trading practices. The reason behind such approach should be sought in an effort to provide an effective system of supplier protection, and this can only be done by removing the initial obstacle for initiating protection proceedings: fear of commercial retaliation (termination of business relation $)^{16}$ against complainant, if suppliers initiate proceedings themselves, and the financial risks involved in challenging such practices (Preamble, No. 8 UTPD).

Member States may designate one ${ }^{17}$ or more competent authorities ${ }^{18}$ to deal with UTPs (Art. 4, para. 1 UTPD). The competent authorities may initiate and conduct investigations on their own initiative or on the basis of a complaint of producer organisations, other organisations of suppliers and associations of such organisations, which is submitted at the request of one or more members of their member organisations. If the complainant so requests, the enforcement authority shall take the necessary measures for the appropriate protection of the identity of the complainant and for the appropriate protection of any other information in respect of which the complainant considers that the disclosure of such information would be harmful to the interests of the complainant or of those members or suppliers. The complainant shall identify any information for which it requests confidentiality (Art. 6, para. 1, point a; Art. 5, para. 2 and 3 UTPD). This rule is an important element for removing the fear of initiating proceedings.

16 The weaker party in the food supply chain is often afraid that initiating proceedings could lead the stronger party (buyers, processors and traders) to terminate the business relationship and therefore refrains from action (http://www.agroservis.rs/nepostene-trgovacke-prakse; https://petir.eu/novosti/poljoprivrednici-se-boje-prijaviti-nepostene-trgovacke-prakse/)

17 Member States have appointed different national enforcement authorities to address UTPs: the national competition authority or a dedicated body, such as a national ministry, a national food agency, or a national anti-fraud agency (Report UTPs, p. 6).

18 In the Republic of Slovenia, the Food Supply Chain Relationships Ombudsman monitors actions by stakeholders in the food supply chain, publishes examples of good business practice on its website, and informs the public thereof in accordance with the regulations governing the protection of personal data and the protection of business secrets (the Agriculture Act, paragraph (1) of Article 61.d). The Ombudsman notifies the Slovenian Competition Protection Agency of any illicit practices in the food supply chain (the Agriculture Act, paragraph (2) of Article 61. d). See: What is the role of the Food Supply Chain Relationships Ombudsman?, https://www.varuhverigehrane.si/eng. 
If the competent authority considers that there are sufficient reasons to act on the complaint, that authority is obliged to initiate, conduct and conclude an investigation within a reasonable time. If it is determined that the buyer has violated any of the prohibitions, the competent authority may require the buyer to: bring the prohibited trading practice to an end (Art. 6, para. 1, point d) UTPD) ${ }^{19}$; impose, or initiate proceedings for the imposition of, fines and other equally effective penalties and interim measures on the author of the infringement, e.g. court proceedings (Art. 6, para. 1, point e) UTPD). The competent authority has the power to regularly publish its decisions (Art. 6, para. 1, point f) UTPD), as well as information relating to buyers that have committed infringements (Preamble, No. 34).

Monetary sanctions must be effective, proportionate and dissuasive. In most countries, which have regulations on UTPs, there is a maximum level of fines in absolute terms, but in some Member States fines are calculated as a percentage of annual turnover of the company that applied UTPs, ranging from $0.05 \%$ to $10 \%$ of turnover. In order to deter traders from engaging in UTPs, penalties should be high enough to outweigh any gain from imposing UTPs and suitable to influence behaviour at company level (should be proportionate to the seriousness of such conduct and its potential harm to victims) (Report UTPs, p. 7-8). The penalties shall be effective, proportionate and dissuasive, taking into account ${ }^{20}$ the nature, duration, recurrence and gravity of the infringement (Art. 6, para. 1 UTPD).

\section{Conclusion}

The adoption of UTPD ended a ten-year process, which took place in parallel at EU level and within Member States, and resulted in the introduction of minimum standards for protection against UTPs, allowing Member States to provide suppliers with a higher level of protection than the one set out in the UTPD.

19 In connection with this request, the Croatian Law on Prohibition of Unfair Trading Practices in the Food Supply Chain contains rules which enable buyer to propose certain measures in order to eliminate indications of UTPs. If Croatian Competition Protection Agency accepts the proposal, it issues a decision suspending the procedure towards the buyer. If during the supervision it is determined that the buyer does not adhere to the proposed measures, the Agency issues a decision on renewal of the procedure, whereby the buyer's behavior is taken as an aggravating circumstance when determining the existence of conditions for imposing a fine (Art. 18).

20 According to the Art. 27 of the Croatian Law on Prohibition of Unfair Trading Practices in the Food Supply Chain, the amount of the fine is reduced or increased depending on the existence of mitigating (cessation of unlawful conduct before initiating proceedings, cessation of such conduct within three months from the date of initiation, short duration of violation, good cooperation with the competent authority conduct of the procedure, contracted unfair practice was not applied to the supplier) or aggravating (repeating procedures that violate legal provisions, refusing to cooperate with the competent authority, encouraging others to violate legal rules, not acting in accordance with the decision to accept obligations, preventing unannounced control of circumstances). 
The legal analysis of the rules, from the general clause to particular forms of UTPs, shows that some of the basic and specific rules of contract law can be identified in the basis of these rules, and that suppliers had the opportunity, even before the adoption of UTPD, to protect themselves against unfair practices in court proceedings with the application of the relevant rules of contract law. However, what makes the adoption of this Directive justified is the fact that contract law, insofar as it encompasses this practice, is not the best mechanism to help suppliers obtain protection. The reason for that is the presence of fear that by filing a lawsuit, they could jeopardize the business relationship with the other party, and thus their own business. In this way, the "fear factor" is eliminated, by ensuring the confidentiality of complaints and conducting the procedure of administrative protection at the initiative of the competent authorities or at the request of relevant organizations and associations.

\section{Acknowledgements}

Paper is written within the Research program of the Faculty of Hotel Management and Tourism in Vrnjačka Banja, University of Kragujevac, for 2021, funded by the Ministry of Education, Science and Technological Development of the Republic of Serbia.

\section{Conflict of interests}

The authors declare no conflict of interest.

\section{References}

1. Commission staff working document Guidance on the implementation/application of directive 2005/29/EC on unfair commercial practices accompanying the document Communication from the commission to the european parliament, the council, the european economic and social committee and the committee of the regions a comprehensive approach to stimulating cross-border e-commerce for europe's citizens and businessesSWD/2016/0163 final. Retrieved from https://eur-lex.europa.eu/ legal-content/EN/TXT/?uri=CELEX\%3A52016SC0163 (September 08, 2021).

2. Directive (EU) 2016/943 on the protection of undisclosed know-how and business information (trade secrets) against their unlawful acquisition, use and disclosure, OJ L 157, 15.6.2016, 1-18.

3. Directive (EU) 2019/633 on unfair trading practices in business-to-business relationships in the agricultural and food supply chain (UTPD), OJ L 111, 25.4.2019, 59-72.

4. Directive 2005/29/EC concerning unfair business-to-consumer commercial practices in the internal market (UCPD), OJ L 149, 11.6.2005, 22-39.

5. Đurović, M. (2013). Opšta zabrana nepoštenog poslovanja u srpskom pravu, Jačanje zaštite potrošača u Srbiji. Pravni fakultet Univerziteta u Beogradu, Beograd, 169-185. [in English: Đurović, M., (2013). General Prohibition of Unfair Commercial Practices Under Serbian Law. Strengthening Consumer Protection in Serbia, Faculty of Law, University of Belgrade, Belgrade, 169-185. 
6. EU kreće u obračun s nepoštenim trgovačkim praksama, Retrieved from http:// www.agroservis.rs/nepostene-trgovacke-prakse (September 18, 2021).

7. European Commission, Unfair Trading Practices in the Food Chain, Retrieved from https:/ec.europa.eu/info/food-farming-fisheries/key-policies/common-agricultural-policy/market-measures/agri-food-supply-chain/unfair-trading-practices en (September 15, 2021).

8. Goldštajn, A. (1980). Privredno ugovorno pravo. Informator, Zagreb. [in English: Goldštaj, A. (1980), Commercial Contract Law. Informator, Zagreb].

9. Jovičić, K. (2017), Kriterijumi kvalifikacije nepoštene poslovne prakse. Pravo $i$ privreda, 55(7-9), 589-600. [in English: Jovičić, K. (2017). Criteria for Qualifying Unfair Commercial Practice, Law and Economy. 55(7-9), 589-600. https://doi. org/10.5937/PiP2103361J

10. Keirsbilck, B. (2011), The New European Law on Unfair Commercial Practices and Competition Law, Oxford; Portland, Oregon: Hart Publishing.

11. Lončar Velkova, M., \& Dabović Anastasovska, J. (2013). Nepoštena poslovna praksa - iskustva EU u primeni Direktive 2005/29/EC, Jačanje zaštite potrošačau Srbiji, Pravni fakultet Univerziteta u Beogradu, Beograd, 154-168. [in English: Lončar Velkova, M., Dabović Anastasovska, J. (2013), Unfair Commercial Practice - EU Experiences in the Application of the Directive 2005/29/EC, Strengthening Consumer Protection in Serbia, Faculty of Law, University of Belgrade, Belgrade, 154-168.

12. Mićović, M., \& Mićović, A. (2018). Potrošačko pravo. Fakultet za hotelijerstvo i turizam u Vrnjačkoj Banji, Univerziteta u Kragujevcu, Vrnjačka Banja. [in English: Mićović, M., \& Mićović, A. (2018). Consumer Law. Faculty of Hotel Management and Tourism in Vrnjačka Banja, University of Kragujevac, Vrnjačka Banja.

13. Mihajlović, B. (2012). Zaštita potrošača od nepoštenog poslovanja. Pravo i privreda, 49(4-6), 538-551. [in English: Mihajlović, B. (2012). Protection of Consumers Against Unfair Commercial Practice, Law and Economy, 49(4-6), 538-551.

14. Mihajlović, B. (2018). Nepoštena poslovna praksa u savremenim uslovima poslovanja. Savremeni pravni promet i usluge, Kragujevac, 803-816. [in English: Mihajlović, B. (2018). Unfair Commercial Practice in Contemporary Business Conditions, Contemporary Legal Transactions and Services, Kragujevac.

15. Mišćenić, E., \& Mamilović, I. (2019). Nepoštena poslovna praksa u hrvatskome pravnom sustavu: uređenje i provedba. Godišnjak Akademije pravnih znanosti Hrvatske, 10(1), 273-299. https://doi.org/10.32984/gapzh.10.1.11

16. Opšte uzanse za promet robom, Sl. List FNRJ, br. 15/54 [in English: General customs for trade in goods, Off. Gazette FPRY, No. 15/54].

17. Poljoprivrednici se boje prijaviti nepoštene trgovačke prakse? Retrieved from https://petir.eu/novosti/poljoprivrednici-se-boje-prijaviti-nepostene-trgovackeprakse/ (September 22, 2021). 
18. Proposal for a Directive on unfair trading practices in business-to-business relationships in the food supply chain (Proposal UTPD), COM/2018/0173 final - 2018/082 (COD). Retrieved from: https://eur-lex.europa.eu/legal-content/EN/ TXT/PDF/?uri=CELEX:52018PC0173\&from=EN (October 01, 2021).

19. Radončić, Dž. (2014). Zaštita potrošača od nepoštene poslovne prakse. Anali Pravnog Fakulteta Univerziteta u Zenici, 7(14), 371-397. [in English: Radončić, Dž. (2014). Consumer Protection from Unfair Business Practices. Annals of the Faculty of Law of the University of Zenica, 7(14), 371-397

20. Regulation (EU) No 1308/2013 establishing a common organisation of the markets in agricultural products, OJ L 347, 20.12.2013, 671-854.

21. Report from the Commission to the European Parliament and the Council on unfair business-to-business trading practices in the food supply chain (Report UTPs), $\mathrm{COM} / 2016 / 32$ final. Retrieved from https:/eur-lex.europa.eu/legal-content/EN/ TXT/PDF/?uri=CELEX:52016DC0032\&from=EN (October 08, 2021).

22. Stojković, J., \& Milićević, S. (2020). SWOT analysis of wine tourism development opportunities in the Trstenik vineyard district. Hotel and Tourism Management, 8(1), 59-67. https://doi.org/10.5937/menhottur2001059S

23. What is the role of the Food Supply Chain Relationships Ombudsman? Retrieved from https://www.varuhverigehrane.si/eng (September 18, 2021).

24. Zakon o obligacionim odnosima, Sl. list SFRJ", br. 29/78, 39/85, 45/89 - odluka USJ i 57/89, "S1. list SRJ", br. 31/93, "S1. list SCG”, br. 1/2003 - Ustavna povelja i "Sl. glasnik RS", br. 18/2020. [in English: Law on Obligations, Off. Gazette SFRY, No. 29/78, 3985, 57/89, Off. Gazette FRY, No. 31/93, Off. Gazette SMN, No. 1/2003 - Constitutional charter and Off. Gazette RS, No. 18/2020]

25. Zakon o trgovini, S1. Glasnik RS, br. 52/19 [in English Trade Law, Off. Gazette RS, No. 52/19].

26. Zakon o zabrani nepoštenih trgovačkih praksi u lancu opskrbe hrane Republike Hrvatske, Narodne novine RH, br. 117/17, 52/21 [in English: Law on the Prohibition of Unfair Business in the Food Supply Chain of the Republic of Croatia], Off. Gazette, No. 117/17, 52/21].

27. Zakon o zaštiti potrošača, Sl. Glasnik RS, br. 88/2021 [in English: Law on Consumer Protection, Off. Gazette of the RS, No. 88/2021].

28. Komentar Zakona o obligacionim odnosima, redaktori Perović, S., Stojanović, D., tom I, Kulturni centar/ Pravni fakultet Univerziteta u Kragujevcu, Gornji Milanovac - Kragujevac, 1980. [in English: Commentary about Law on Obligations, ed. Perović, S., Stojanović, D., vol. I, Cultural Center/ Faculty of Law,University of Kragujevac, Gornji Milanovac - Kragujevac, 1980. 